Eric Landowski

Con el humor no se juega

La prensa política y sus caricaturas

(traducción de Gabriel Hernández Aguilar)

I. Reír de lo político

Si la política no fuera conducida por los hombres, si (al igual que las imperceptibles variaciones atmosféricas o los grandes sacudimientos telúricos) no fuera más que una serie de cambios naturales sobre los cuales no tendrían influencia ni la intervención de los individuos ni la de los grupos sociales, ella ciertamente no perdería nada de la dimension dramática que reviste episódicamente a los ojos de todos, cada vez que la rutina de los enfrentamientos cotidianos se transforma en situación de crisis. Pero precisamente, ningún evento, si es de orden político, pone en definitiva al hombre frente a otra cosa que a sí mismo. Es él, y no un puro juego de fuerzas que lo rebasan, quien forja colectivamente su propio destino, en la armonía o en la lucha. Y, sin duda, es por esa razón - porque una responsabilidad humana se encuentra ahí siempre comprometida - que lo trágico de la política alcanza tan difícilmente lo absoluto; los dramas que vivimos en ese plano no traducen más que la finitud, la ceguera o la maldad de los hombres y, en ese sentido, por insostenibles que sean muchas veces, aún hacen parte de la "comedia humana". 
Ésa es, al parecer, la "filosofía" implícita que subtiende a la posibilidad, a primera vista sin límite, de reír de lo político. En la prensa, algunos fotografos, cronistas y, sobre todo, caricaturistas y dibujantes, hacen de ello una especialidad reconocida incluso en los periódicos reputados más "serios", respondiendo asf, aparentemente, el gusto del público por un estilo periodístico autónomo, satírico o juguetón, paralelo al discurso de la "información" propiamente dicha: en Francia, son creadores como Konk, Plantu, Pancho o Serguei, Sarraute o Frossard, solo por citar a los grandes "periodicos de referencia" (Le Monde, Le Figaro); el elenco se extendería considerablemente si, de Sempé a Wolinski, de Cabu a Trez, de Siné a Wiaz, se quisiera hacer un recuento aunque fuera sólo de las principales firmas de la prensa semanal o mensual.

"Haciendo humor" de todo, y principalmente de los grandes de ese mundo, ¿qué papel cumple entonces ese discurso de acompanamiento? ¿Introduce sólo un poco de "alegría" en medio de un universo, por otro lado, más bien austero? O bien, ¿se encarga, al mismo tiempo, de algo más que permita explicar mejor su presencia - quizás menos marginal de lo que parece- en el contexto de la "comunicación política" de los periódicos en donde lo encontramos?

\section{Juego de simulacros}

\section{II.1. El basamento polémico}

La primera explicación en la que se puede pensar para dar cuenta del hecho de que humor y política constituyen en el fondo una muy buena pareja es que si, de un lado, la política consiste en un combate entre fuerzas concurrentes o adversas, del otro, el humor tiene, desde esa perspectiva, para cada una de las partes que se enfrentan, las virtudes de un arma inmediatamente al alcance de la mano.

Ciertamente, la política no se reduce a su componente polémico, y, por otra parte, sería aportar una definición empobrecedora del hu- 
mor que, de una manera general, pretende asimilarlo a una simple manifestación de agresividad. Al lado de la risa cáustica, destructiva, partidaria, hay lugar, hasta en la política, para otras formas de imisión que, probablemente, no surgen todas de la vena militante y del humor combativo. Sin embargo, esa primera dimensión existe y persiste, suministrando hoy en día, en todo caso cuantitativamente, lo esencial de la temática explotada por los periodistas humoristas. De hecho, incluso si, como se dice, el ridículo "no mata" al adversario, él puede hacer vacilar a las mejores reputaciones, puede corroer y deshacer los simulacros, desfigurar y reconfigurar a destiempo las imágenes de marca, mientras tanto es precisamente por su buen porte que se miden cotidianamente los niveles de "popularidad".

¿C6mo operan entonces los humoristas para realizar ese trabajo de zapa?

\section{II.2. El ser y el parecer}

Técnicamente hablando, existen procedimientos simples en su principio y relativamente probados, aunque en ese dominio el éxito no esté, por supuesto, asegurado jamás automáticamente. La receta más elemental, conocida por todos los ironistas que quieren divertir a su auditorio a expensas de algún '"chivo expiatorio", descansa en una substitución programada entre simulacros. Más precisamente, se trata de relacionar, a propósito de lo que se toma por blanco, dos imágenes lo más claramente antitéticas entre sí como sea posible: por un lado, en general, aquella, lisonjera, que quiere dar de sí misma la víctima potencial de la operación -imagen convenida pero destinada a caer como si fuera una máscara- $-y$, por otro lado, aquella que se propone substituirla en el cambio de punto de vista adoptado con el fin de provocar la risa o la sonrisa, la cual, tomando sistématicamente el ángulo contrario de la precedente, supuestamente revelará la "verdad" escondida bajo el "parecer".

El dibujo de Konk (figura 1) —un clásico en la tradición de Hergé ( $c f$. Anexo 1) — ilustra ese dispositivo de manera ejemplar. 


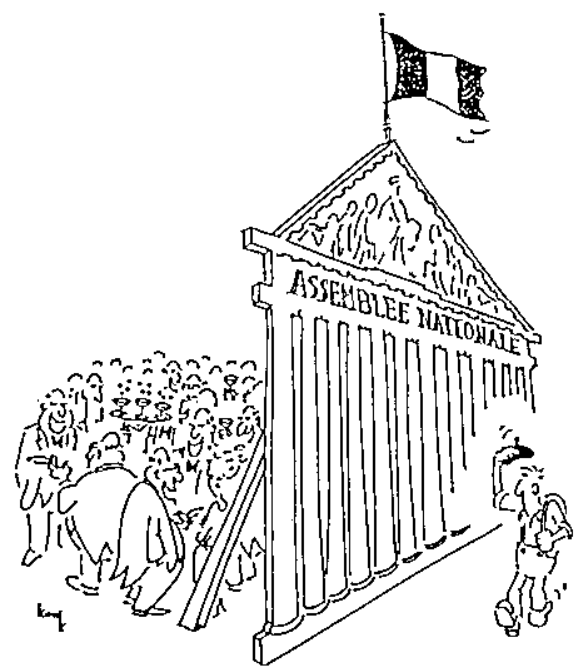

Figura 1: Dibujo de Konk.

Jugando al mismo tiempo çon la dualidad de los planos constitutivos del objeto representado —en donde, mirando de derecha a izquierda, se descubre primero el exterior (la fachada), después el interior (lo que sucede detrás de esa fachada) - y con el desdoblamiento de los puntos de yista "subjetivos" correspondientes (aquel, "exterior", del transeúnte, después el "nuestrọ", que penetra al "interior" del edificio), el dibujo de Konk plantea explícitamente los dos términos de la relación contradictoria en la cual se funda el discurso irónico: así como la majestad emblemática del frente exhibido del edificio justifica el gesto de respeto del transeúnte que "se quita el sombrero", el descubrimiento de su cara escondida demuestra la ingenuidad del "buen francés" que se ha dejado engañar por las apariencias del decorado, sin ver el reverso. ¿Cómo podría, además, ser de otra manera? Dentro del espacio figurado en el enunciado, se le asigna a nuestro personaje una posición por definición "ciega", a partir de la cual es perceptible sólo uno de los elementos constitutivos del paradigma de las representaciones posibles de la institución contemplada. En cuanto al término comple- 
mentario, único "verídico" en el ejemplo, corresponderá la exclusiva de su descubrimiento a los lectores desilusionados que somos por construcción, teniendo en cuenta la puesta en perspectiva englobante producida enunciativamente sobre el objeto.

A esa pedagogía de demistificación un poco insistente, que araña explícitamente tanto la "hipocresía" de las élites como la "inocencia" de las masas, se pueden evidentemente preferir burlas menos laboriosas que, incluso si se apoyan en el fondo sobre un esquema estructural idéntico, al menos lo explotan en un modo más elíptico. Veamos, a manera de ilustración, la figura 2, donde la impertinencia discreta, e incluso gentil, contrasta con el contenido doblemente mordaz del dibujo precedente.

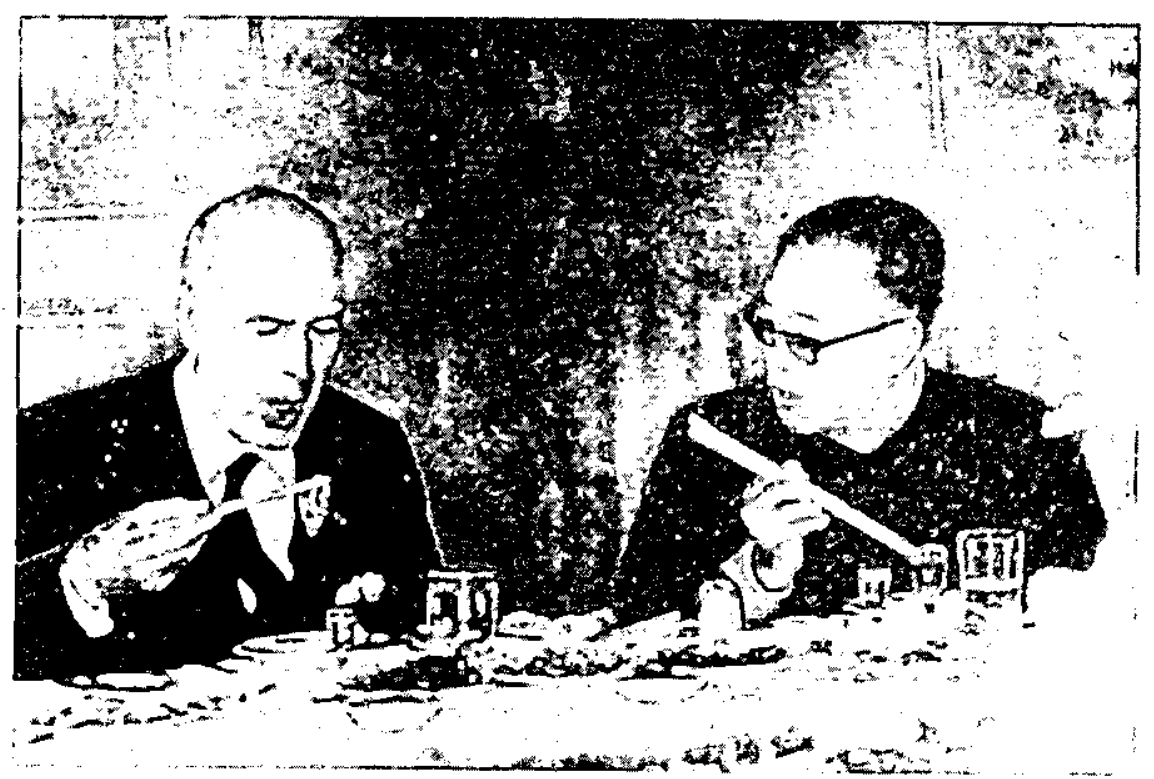

Diner aux baguettes avant les toasts politlques pour Valéry Giscard d'Estaing et son hôte, le premier ministre chinols Zhao Ziyang.

Figura 2: Le Figaro, 16 octubre 1980. 
Como en el ejemplo anterior, el efecto humorístico nace del encuentro entre el querer parecer de un sujeto, aquí individual y no ya colectivo, y ciertas circunstancias responsables de su fracaso, actual o previsible. El primer elemento quedará, en esta ocasión, dentro de un programa presupuesto, pero no es nada difícil reconstruirlo: si se es jefe de Estado, es necesario conducirse como tal en todas las circunstancias, es decir, asumir el cuidado de su dignidad hasta en los más pequeños detalles con por los menos una apariencia de soltura. Por el contrario, el segundo elemento está planteado explícitamente en la imagen gracias a la malicia del fotografo: he ahí a nuestro presidente tomado flagrantemente en situación embarazosa, en el límite de un paso en falso dadas las exigencias de su propia etiqueta. Además, la mirada ligeramente compasiva, quizá inquieta, de su anfitrión, subraya ell lado peligroso de la situación. Efectivamente, ¿qué pasaría si por desgracia el augusto invitado no logra salir airosamente de la prueba a la cual lo somete el manejo, visiblemente delicado, de los palillos? Guardando toda proporcion, le quitaría su dignidad. Por supuesto, no es que un incidente sobre un plano tan anodino pueda, en sí mismo, acarrear alguna consecuencia. No obstante, un fracaso de ese orden equivaldría al reconocimiento de lo ficticio del simulacro bajo los rasgos del cual nuestro héroe, de açuerdo con la concepción que tiene de su funcion, evidentemente pasa ante los ojos del público. En una palabra, nada debe permitir a cualquiera sospechar que el personaje, tal como se muestra, difiere de la persona "como es en sí misma", con su manera de ser "al natural". Ya que dejar entrever, así sea sólo un poco, que al ejercer la función presidencial se está asumiendo una especie de papel prestado, eso en sí mismo implicaría ya no ser más presidente. En otras palabras, si hay algo de cómico ahí, no resulta, o en todo caso no únicamente, del espectáculo de una infracción inminente al código de las maneras de mesa. Remite y es ahí donde volvemos a encontrar el dispositivo ya ilustrado por el dibujo de Konk al hecho de que asistimos a la puesta en evidencia de la construcción de un simulacro justo cuando corre el riesgo de derrumbarse. 
El documento que sigue (figura 3) va un poco más adelante a partir de un esquema estructuralmente comparable. Como en la figura 2, tenemos aquí dos personajes, uno que "actúa" mientras el otro lo mira hacer. Con más o menos la misma atención con la que Zhao Ziyang vigilaba las evoluciones de Valéry Giscard d'Estaing, Juan Pablo II observa a Jimmy Carter. Sin embargo, ¿qué hace en realidad este último? La leyenda nos informa que el Santo Papa acaba de dar su "mensaje"; se comprende entonces que el presidente de los Estados Unidos está aplaudiendo. Pero al mismo tiempo, la astucia del fotógrafo es la de haber captado el gesto de las manos y, más generalmente, la actitud global del presidente americano en un momento y bajo un ángulo que permiten también asimilarlos a los gestos del rezo'. Ahora bien, se notará que, de

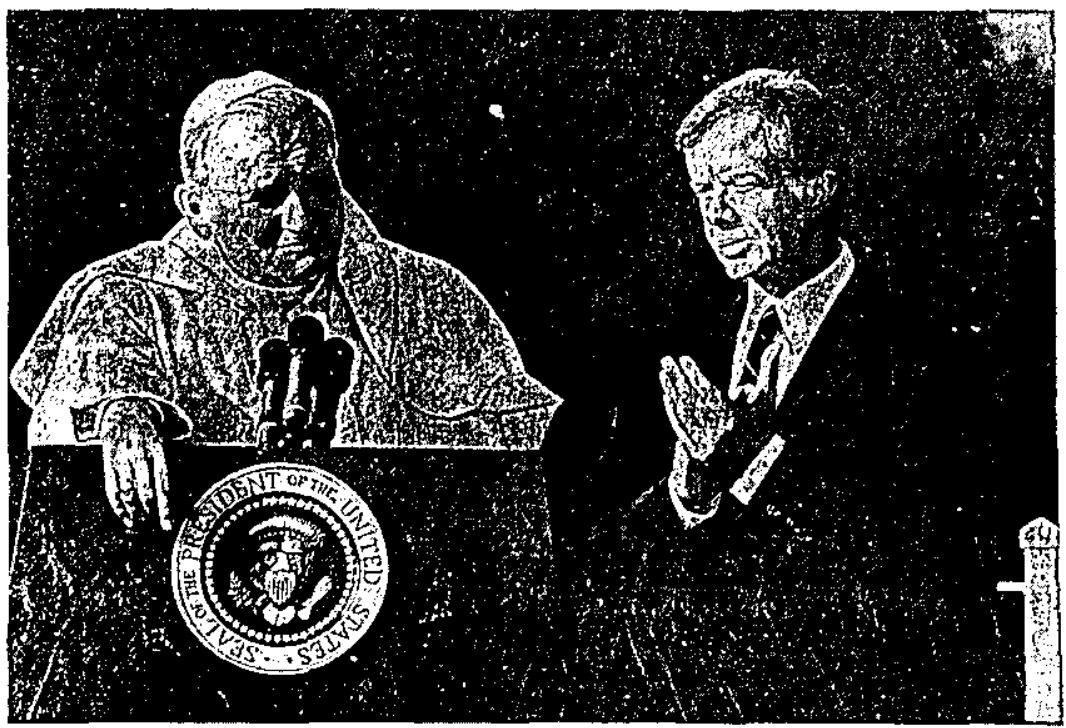

Jean-Paw If apporte au monde le message de notre clvilisation.

Figura 3: Le Figaro, 31 octubre 1971.

'Sobre esa temática aparentemente muy apreciada por el Figaro al menos en el caso del presidente Carter, ver también los Anexos 2 y 3. 
una a otra de esas dos lecturas posibles, las relaciones entre los protagonistas se invierten: o es el jefe de Estado quien congratula al hombre de Iglesia por la calidad política de su discurso o, por el contrario, es el jefe de la Iglesia quien evalúa las cualidades del hombre político en el ejercicio de un rito religioso.

Si nos quedamos con esta segunda interpretación, (la única que permite saborear la sal y pimienta de la situación), observamos que la función presidencial, de uno y otro lado del Atlántico, pasa por el cumplimiento de lo que los folkloristas, después de Vladimir Propp, llaman "tareas difíciles". Se admitirá, sin duda, que hacer uso elegantemente de palillos, para un europeo, o concentrarse sin ostentación, aunque sea en público, en una actitud de piedad, no debe ser fácil en ningún caso. Pero, que sea necesario, además, arriesgarse a hacerlo ante la mirada de expertos (si se puede decir) tan eminentes en esas materias como el jefe de la diplomacia china o como el papa en persona, eso supone decididamente talento y sangre fría. Eso es, nos parece, lo que confirma la expresión de Juan Pablo II frente a la audaz actuación de su interlocutor: una cierta condescendencia marcada por la extensión de la mano y la inclinación de la cara, cierto rasgo de sorpresa en la mirada y, en definitiva, una expresión como de hastío o de duda, pero en definitiva de aprobación de la parte de un buen conocedor. Así, en oposición al "fulano" que, en la figura 1, se dejaba engañar, sin más, por la apariencia de las cosas, nos enfrentamos aquí a un observador taimado, instruido en la apreciacion de las almas, y que parece soplarnos esa pregunta tan impertinente como decisiva: ¿por azar el presidente de los Estados Unidos, en ese momento, frente a nosotros, se recogerá realmente? O bien ¿está simulando?

\section{II.3. ¿Humor o ironia?}

Por caminos más o menos apartados, así volvemos siempre a una sola y misma búsqueda: se trata de saber qué "realidad" hay de- 
trás del decorado, qué "verdad" detrás de la pose y, finalmente, qué hombre detrás del actor político.

Si la pregunta, planteada bajo esa forma genérica, representa una constante, la respuesta, por el contrario, no será siempre clara, ni incluso siempre necesaria. Hasta cierto punto, poco importa en efecto que la significación final de los elementos puestos en escena esté claramente dada, como era el caso en la figura 1 donde, deliberadamente, se pretendía "levantar el telón" o, por el contrario, que la pregunta que surge al poner en evidencia el lado enigmático de las apariencias sea dejada en suspenso, como en las dos escenas de la vida presidencial cuyo análisis acabamos de esbozar. Porque si existe una insolencia extrema al exponer la figura del "rey desnudo", ya hay bastante impertinencia al insinuar, frente al príncipe, que, quizás, el espectáculo que nos ofrece de sí mismo es sólo un juego de máscaras. Con esta segunda formula, el humor - el de la sospecha más que el de la denuncia, el de la duda más que el de la franca demistificación - no pierde necesariamente nada de su causticidad; pero gana seguramente en "fineza".

Quizás, por lo demás, no se trataría, hablando propiamente, de "humor" si no hubiera este tipo de suspenso: si el enunciador (dibujante o fotógrafo) intenta ser "humorístico", él tiene que abstenerse, por principio, de proveer en el enunciado (en el dibujo o en la foto) cualquier indicio que permitiera arbitrar demasiado rápido entre dos o varias lecturas posibles. No dar, sobre todo no dar de entrada la clave del enigma, evitar en particular despejar la ambigüedad relativa a su propio grado de adhesion en relación a la "realidad" de lo que se muestra (o a la "verdad" de lo que se dice), todo eso pertenece al estilo "mátalas callando" propio a todos esos usuarios un poquito perversos del lenguaje (verbal u otro) que son los verdaderos humoristas.

También, para ser claros con la terminología, valdría más hablar simplemente de ironía cuando esa parte determinante de indecidibilidad concertada falta o cuando se adelgaza al punto de dar lugar, en última instancia, a la aserción apenas desviada de alguna 
"verdad" claramente asumida por el enunciador (caso ilustrado ya por la figura 1). La figura 4 ofrece un ejemplo similar, con la única diferencia de que la revelación no se produce más, aquí, sobre el modo del descubrimiento sino que procede de una pura y simple comprobación: el "conocimiento verdadero", aquel del envés del decorado, no se descubre esta vez gracias a un cambio de punto de vista del observador en relación al objeto, está dado inmediatamente por el comportamiento del sujeto observado, quién, con toda inocencia (aunque a la defensiva), nos informa de su propia incompetencia sobre el modo de la confesión (cf. también Anexo 4).

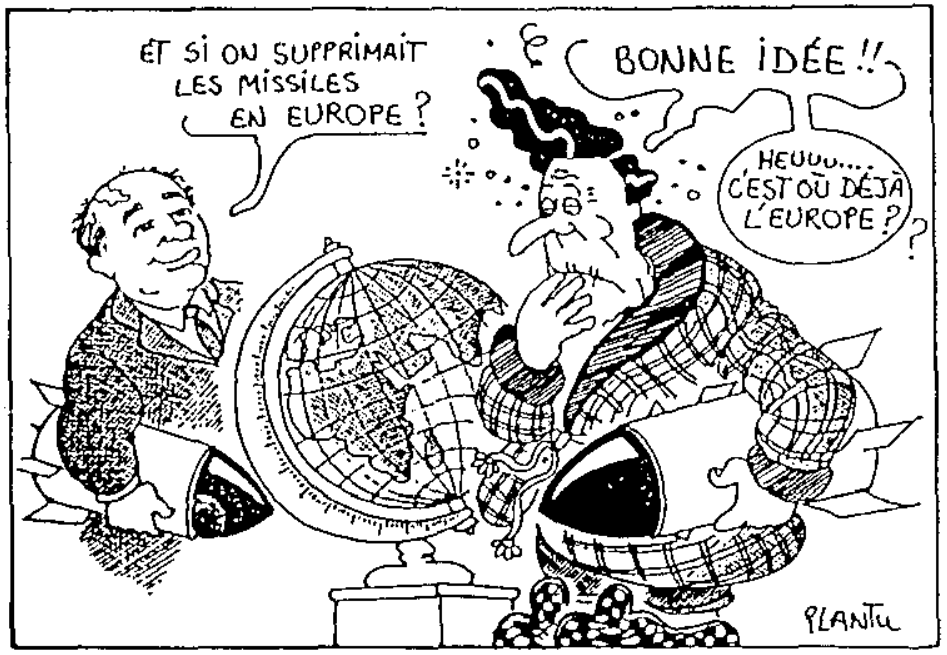

ETATS-UNIS - URSS : Washington replique, le mars, is proposition de A. Gorbatcher en depocant 1 Genźve on projet de traité sur ke démantżiement des euromissiles.

Figura 4: Dibujo de Plantu

En definitiva, que se muestre ella misma o que haga falta encontrar el ángulo bajo el cual penetrarla, la realidad es fundamentalmente conocible por el ironista: su discurso es el de la transparencia de las cosas. Correlativamente, deberían ser entonces calificadas de "humorísticas" en sentido estricto, o en sentido fuerte, sólo las pro- 
ducciones que, sistemáticamente, preparan las condiciones para un balance posible entre dos o varias interpretaciones mutuamente exclusivas. Desde ese punto de vista, la figura 5 proporciona un excelente ejemplo de humor. incluso si, por fin, afirma bien "algo" a propósito de lo político, nos obliga en todo caso a diferir el momento de decidir sobre lo que supuestamente "quiere decir".

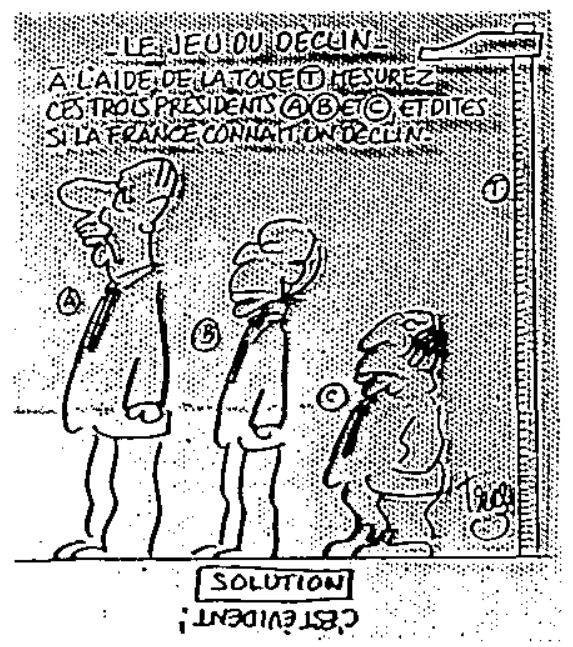

Figura 5: Dibujo de Trez

En un plano muy general, nada permite a priori privilegiar una u otra de las dos posibilidades que acabamos de distinguir. En teoría, humor e ironía coexisten "en igualdad" como formas utilizables para estrategias de imrisión diversificadas. Pero no ocurre lo mismo en la práctica. Así, lo sabemos, en ese dominio cada cultura tiende a optar en función de predilecciones que le pertenecen y que, según el caso, pueden inclinarse en un sentido o en otro. Si el "humor", se dice, es británico (o checo o polaco), por el contrario, se considera a menudo que el perfecto dominio de la ironía es un rasgo característico del "genio francés". Queda claro, sin embargo, que por sí misma la evocación de tendencias tan globales no explica todo y que si se quiere dar cuenta un 
poco más precisamente de la diversidad de los usos reales, otros factores, otras variables más específicas, deben ser tomadas en consideración.

Si podemos entonces postular que uno no ríe de todo de la misma manera, la primera de las variables a introducir con el fin de mejor comprender cómo se ríe se va a relacionar a la cuestión de saber de qué uno ríe. Al menos esa manera de abordar el problema nos acercará directamente al dominio más circunscrito que nos debe retener aqur: ¿cómo se ríe uno de lo político? Ahora bien, a primera vista es bastante extraño constatar que, cuando es de eso específicamente de lo que se trata, el desequilibrio entre las dos grandes formas del humor que consideramos llega a ser particularmente patente. Con excepción de un pequeño número de casos — como por ejemplo el dibujo de Trez aquí arriba- una de las dos formulas disponibles permanece sistemáticamente subexplotada, mientras que la otra es incansablemente utilizada de muelle: ¿por qué un humor relativamente tan raro y por qué, en contrapartida, tanta ironía frente al "poder"?

\section{En busca de certezas}

Por sí mismo, el contexto en el interior del cual se ejerce la inspiracion de nuestros "humoristas" (en el sentido amplio), parece explicar en buena medida el privilegio así acordado a la forma de lo cómico que es, si no la más "fina", ni probablemente la más chistosa, en contrapártida, la que menos riesgo tiene de perturbar la tranquilidad intelectual de los lectores.

De hecho, en oposicion al discurso humorístico (en sentido estricto) que, por principio, incluso cuando no se transforma en $h u$ mour noir pero conserva una tonalidad más o menos euforica, nos instala, guardando toda proporción, delante de un universo fundamentalmente inquietante: porque nunca afima ninguna verdad definitiva, el discurso del ironista propone un mundo perfectamente inteligible y tranquilizante en la medida en que las certezas que 
podemos adquirir si lo escuchamos siempre nos aparecerán como la contraparte positiva de la pérdida de alguna "ilusión" anterior. Si se acepta ese punto de vista, ironizar es simplemente una manera de apostar sobre los poderes de la razón al asignar a toda cosa, con una insistencia particular, un sentido, su sentido, el "verdadero", o al menos el que como ironista se busca hacer pasar por tal (y que el humorista, por su parte, cuestionaría).

Si es así, ironizar especialmente sobre la política, ¿es reirse de ella verdaderamente? O bien, por el contrario, ¿no es una manera indirecta de tomarla decididamente muy "en serio" y de decir, o de reafirmar a quien podría dudar, que sí tiene un' sentido, aunque fuera diferente del que se exhibe en la superficie?

Tomando en cuenta esas características "intemas", intrínsecas a cada una de las formas de "humor" que hemos aislado, es fácil comprender cómo un segundo conjunto de factores, de orden "externo", contextual, pesan en las estrategias de quienes, en particular en la prensa, tienen como profesión la de divertimos tomando como pretexto los asuntos políticos.

\section{III.1. Régimen contextual}

Ante todo, el lugar donde un creador publica, y el marco editorial en función del cual sus dibujos, sus fotos o sus textos son concebidos, no pueden ser elementos indiferentes. Sin que haya necesidad de emprender un laborioso análisis de las "condiciones de produccion" de las obras que tenemos en perspectiva, se puede adivinar, en efecto, que no se juega con la política de la misma forma si se trabaja para una revista especializada del tipo del $\mathrm{Ca}$ nard enchaîné o si se publica independientemente, en album, bajo contrato con un editor, o si se dispone de una página entera en un semanario o, incluso, si se interviene regularmente en la "primera" de un gran periódico. Si esta última situación parece la más envidiada en la profesion, es probablemente también donde las exigencias editoriales son más fuertes. 
Por supuesto, en el equipo de un periódico, caricaturistas y cronistas gozan en general de un estatuto un poco aparte, el cual les permite, hasta un cierto punto, como se dice en la primera página del Figaro, hacerla de "jinete solitario" ( $c f$. figura 6). Entretanto, son periodistas que "forman parte de la casa" y no pueden traicionar sistemáticamente su "espíritu", incluso si, por una especie de regreso reflexivo y burlón sobre su propia condición -de lo cual el dibujo de la figura 6 constituye un ejemplo- les es siempre posible seguir haciendo ironía (en "segundo grado") a propósito de las consignas mismas, de preferencia maliciosamente reformuladas, que la Redacción les impone.
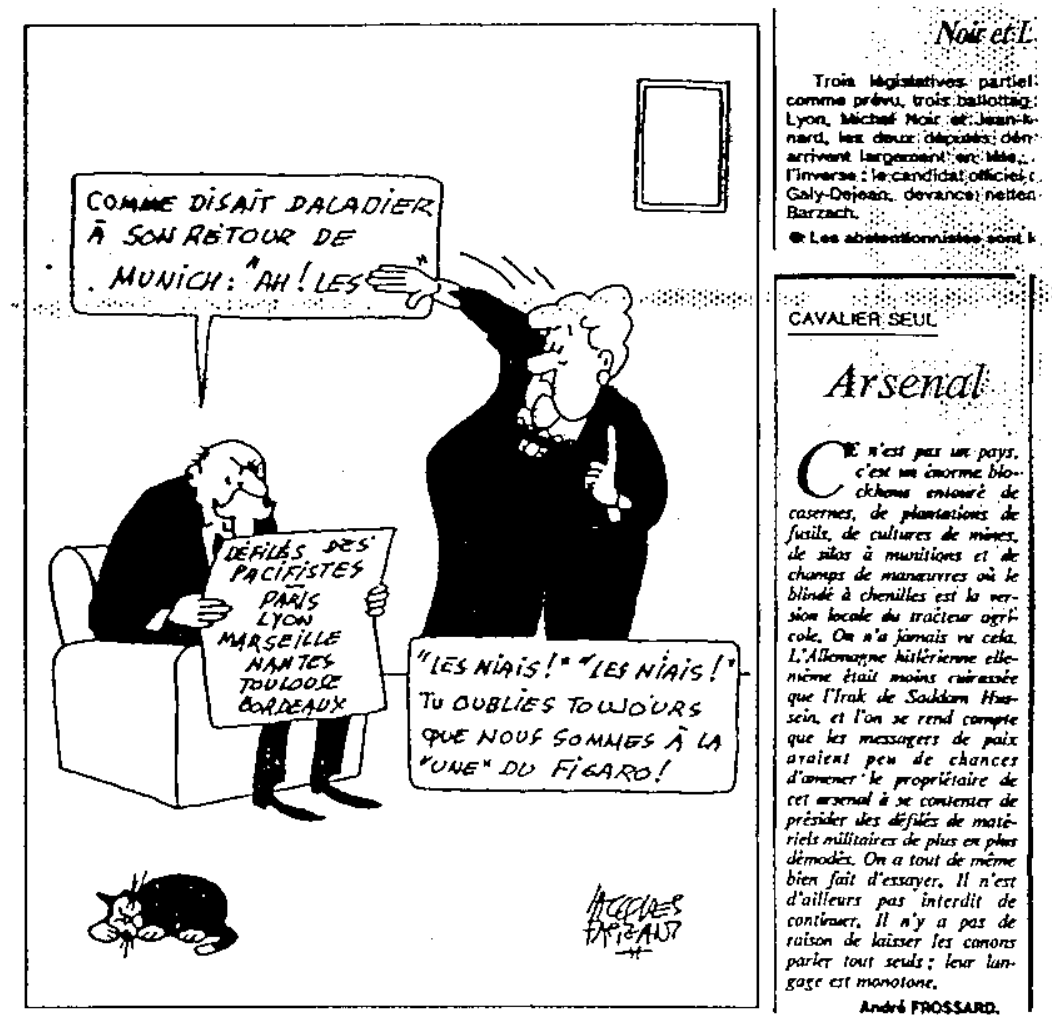

Figura 6: Dibujo de J. Faizant y texto de A. Frossard 
Tenemos ahr un primer acercamiento posible del "contexto". Así sea insuficiente e, incluso, trivial, permite al menos suponer sin gran riesgo que la elaboración del material que nos ocupa obedece a ciertas reglas, en el ejemplo de origen "institucional" (bajo la condición evidentemente de admitir que un perí́dico, con su aspiración a permanecer, su "imagen" a defender afuera y su rigidez intema, constituye, a su manera, una especie de institución). Sea como sea, tal contexto no excluye toda libertad de creación. La inventiva, cada día renovada, del rasgo o de la puntilla de los humoristas es testimonio suficiente de lo contrario. Lejos de bloquear a los talentos, la institución lós llama y, en gran medida, parece darles carta blanca: ¿qué le aportan, pues, en el ejercicio mismo de esa relativa libertad de expresion?

Regresaremos a esa pregunta, pero hay antes algo más preciso que es necesario subrayar si, dejando de lado las evidencias de orden "sociologicas", pasamos a un segundo acercamiento, discursivo, del contexto. Tal vez no descubriremos, por esa vía, más que otra serie de evidencias, pero, al menos, a diferencia de las precedentes, ellas procederán de la observación directa del material del que se dispone, es decir, de las imágenes en contexto que el lector encuentra efectivamente bajo sus ojos y cuya organización tiene o no tiene por efecto el de hacerle reír. Tomemos como ejemplo la "primera" de Le Monde del 21 de enero de 1991 (figura 7).

$\mathrm{Si}$, ni más ni menos que muchos otros, el grafismo de Plantu que ilustra este número tiene sentido y puede pasar como divertido, se debe evidentemente, en gran parte, a que se encuentra yuxtapuesto, asociado, directamente mezclado con la presentación de las informaciones del día: a tal punto que se podría decir que los dos grandes títulos de los reportajes provenientes de Washington y de Jerusalem, que aparecen resaltados un poco más abajo en la página, constituyen su "leyenda". Una leyenda a contra corriente, por supuesto, dado que los principales elementos de la situación resumida por esos dos títulos se encuentran exactamente intercambiados en el dibujo. De hecho, al observar la actitud agitada, el gesto implorante (casi asustado), la cara contraída del presidente 


\section{些e 粞onde}

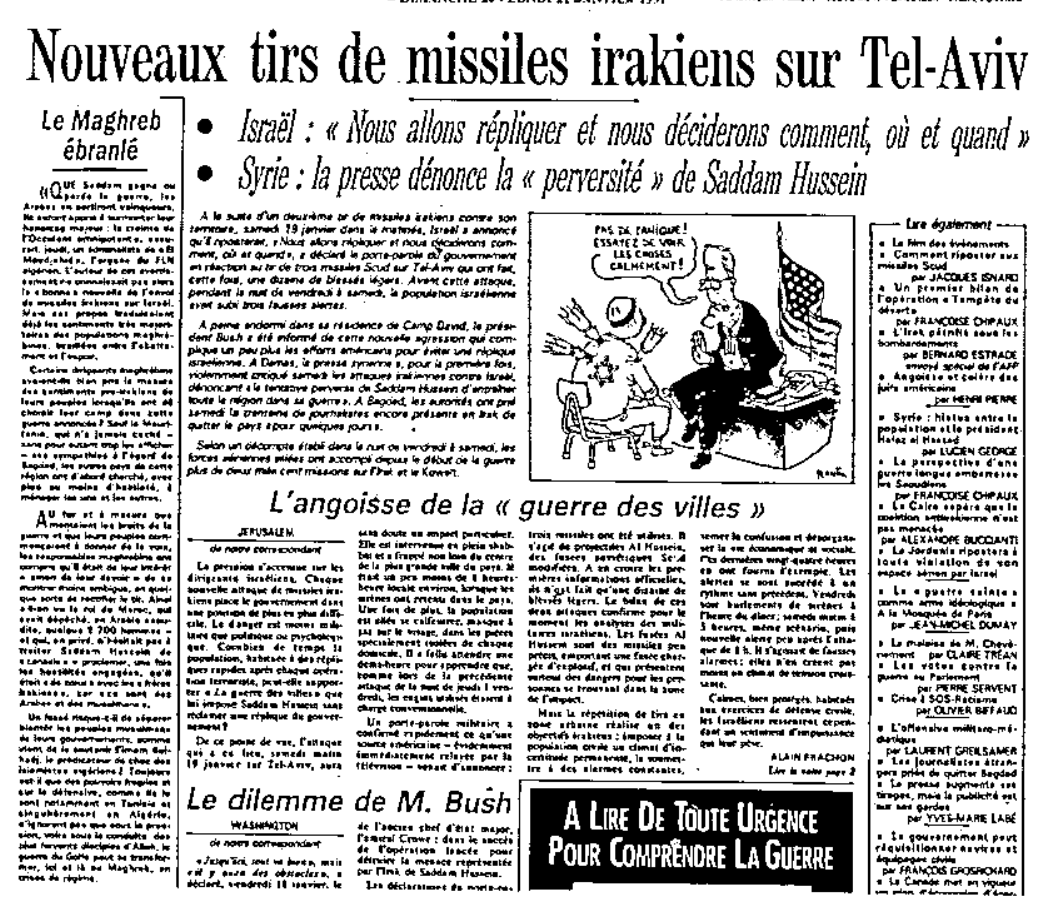

Figura 7: Dibujo de Plantu 
americano quien, literalmente, está fuera de su asiento ¿no es evidente que en realidad es en Washington, y no en Jerusalem, donde se siente "la angustia", y que es, por el contrario, del lado de aquellos delante de quienes el verdadero "dilema" se plantea (entre la "réplica" y la "discreción" frente a los tiros de misiles), que uno conserva su sangre fría?

El efecto irónico que de ahr resulta es doble. Primero, al intercambiar así los "estados de alma" de los protagonistas, el dibujo nos dice en el fondo que es el más fuerte quien tiene más miedo, lo que tiene ya en sí algo inesperado y picante. Pero no es todo. Desde que, ironizando de esa manera sobre el presidente Bush, el autor del dibujo nos dice lo contrario de lo que, en el contexto de la misma página, nos es reportado por sus colegas de Washington y de Jerusalem, es también, al mismo tiempo, sobre ellos (o al menos sobre la relatividad de su punto de vista) que él se pone a ironizar, aunque sea indirectamente. Así, a una primera pregunta - ¿de qué exactamente se nos hace reír en ese dibujo?- - se subordina otra: ¿de quién, al hacerlo, se burla uno sin decirlo?

\section{III.2. Referencia y deconstrucción}

Un desdoblamiento formalmente comparable había aparecido ya en el examen de nuestro ejemplo de partida (figura 1). Recordamos que, para alcanzar su meta principal y explícita se trataba en el ejemplo de los parlamentarios, acusados de hipocresía el discurso irónico de Konk arañaba también, en su recorrido, una segunda meta, más borrosa, en la persona de ese transeúnte exageradamente confiado en la majestuosidad de las instituciones, víctima de su propia "inocencia" y del decorado levantado para abusar de él. De la misma forma, la burla de Plantu contra el presidente de los Estado Unidos pasa por un amigable y discreto cuestionamiento, esta vez no de la credulidad del francés medio personaje mítico, lejano y anónimo- sino de la credibilidad de sus muy cercanos colegas periodistas, vistos implícitamente 

la Casa Blanca.

En ambos casos, si el discurso irónico alcanza su objetivo proponiendo un cierto simulacro, "negativo", de su objeto (aquí, la visión de un Parlamento sin moral, allá, un presidente aparentemente desamparado), no es sólo en la medida en que la imagen que propone remita, contradiciéndola, a una imagen contraria, "positiva" (la de un Parlamento realmente digno de respeto, o la de un presidente que permanecería sereno en la adversidad); es también en la medida en que ese simulacro positivo puede él mismo aparecer como traduciendo el punto de vista efectivamente adoptado por algún tercero, sea individual (el transeúnte) sea colectivo (los periodistas de Le Monde), claramente identificable en el marco de un contexto discursivo algunas veces muy próximo, otras veces más lejano. Dicho de otra forma, el ironista necesita en todos los casos del "discurso del otro" o, en términos un poco más técnicos, de un discurso de referencia.

El estatuto, al.igual que la procedencia de tal tipo de discursos, que todo ironista va a tener que convocar con el único fin de deconstruirlos, podrán ser muy diversos. En el caso de la caricatura en el sentido primario y lo más general del término el discurso que va a servir de referencia y a encontrarse entonces en definitiva deconstruido, será simplemente aquel, implícito, que constituye la visión "natural", a priori, que tenemos del modelo antes de que haya sido retratado ${ }^{2}$. Será a esa apercepción primera, necesaria-

\footnotetext{
${ }^{2}$ No hay ninguna razón, en la perspectiva semiótica que aquí adoptamos, que nos obligue a restringir el empleo del términó de "discurso" solo a las producciones de naturaleza lingüística; una imagen, una actitud, una mirada serán, para nosotros, al igual que el texto, "discursos"-discursos plásticos, gestuales, u otros, siempre susceptibles de servir de referencia a otros discursos... en su turno verbales, plásticos u otros. Sobre el conjunto de las opciones teóricas y metodológicas subyacentes a ese trabajo, $c f$. A. J. Greimas y J. Courtés, Sémiotique. Dictionnaie raisonné de une théorie du langage, París, Hachette, vol. I, 1979 [versión española: Semiótica. Diccionario razonado de una teoría del lenguaje, Madrid, Gredos, 1982]; E. Landowski, La Société réfléchie. Essais de sociosémiotique, París, Seuil, 1989 [versión española: La sociedad figurada, México, FCE, en prensa].
} 
mente presupuesta - a esa especie de discurso interior que elaboramos para nosotros mismos frente al mundo sin tener necesidad de enunciarlo- que el dibujante va a tratar de substituir por una esquematización construida de manera diferente que se impondrá con mayor evidencia y que logrará hacer resaltar ciertos rasgos plásticos del "original" hasta entonces inadvertidos; al punto de parecer, quizás, "más verdadero" que lo natural.

El caso de la caricatura política obedece a los mismos principios generales, pero agrega ciertas determinaciones más particulares. Incluso si jamás se priva de enriquecer a su manera - -es decir, por la acentuación sistemática de las incongruencias o de las deformidades - nuestra visión "estética" de los hombres que encarnan el poder, ella se limita raramente a intervenir en ese plano. Evidentemente, pretende hacemos descubrir lo que se esconde detrás de las máscaras. Así, la esquematización de lo "físico" servirá sobre todo de soporte figurativo a la revelación de los caracteres, al igual que, en una perspectiva más dinámica, las manipulaciones del espacio, y en particular las distorsiones de las proporciones, en el tratamiento del tamaño de las figuras, servirán de procedimientos convencionales para traducir en imagen la redefinición irónica de las relaciones entre los protagonistas de una acción o de una escena políticas ( $c f$. Anexo 5).

Sin embargo, para permitimos el acceso a la "verdad" de los seres y de sus relaciones, no bastaría con hacernos ver a través de una mirada nueva ciertas fisonomías o ciertas siluetas familiares al deconstruir con esa intención los esquemas de percepción, de orden puramente visual, que utilizamos "espontáneamente". Será necesario deconstruir también toda clase de esquemas de representación de orden cognoscitivo que, objetivados esta vez en discursos de referencia efectivamente enunciados y, en consecuencia, socialmente localizables, solicitan nuestra adhesión al presentarse como portadores de alguna verdad relativa a lo que dicen o a lo que ponen en escena: toca a los ironistas convocarlos, citarlos, y neutralizarlos, con el fin de alejar — si así podemos decirlo- el riesgo que nosotros asumimos, es decir, el riesgo que nos 
embauquen en nuestra actividad de juicio sobre los hombres que nos gobiernan.

Tres tipos de embaucadores -es decir tres clases distintas de discursos de referencia diversamente "deconstruibles"-- pueden teóricamente presentarse, según la localización de la instancia de la que emanan. Podrán, en efecto, encontrar su origen o bien en una empresa de mistificación deliberadamente conducida por el actor político mismo, o bien en un proceso de autosugestion donde se encierra algún tercero colocado en posición de observador en relación a ese actor o, en fin, en un trabajo de desinformación ordinariamente efectuado, como se debe, por algún "informador" profesional que se supone nos informa sobre el desarrollo de la acción. En los tres casos hay materia para la ironía, así como ya lo mostraron los diferentes ejemplos revisados más arriba: ironía sobre el discurso de los actores, con las fotografías de las mímicas, bien o mal controladas, de los jefes de Estado tratando de cuidar su imagen frente a las cámaras ("mistificaciones", quizás anteriomente abortadas: figuras 2 y 3); sobre el discurso del observador, como en la figura del francés medio retirando su boina -símbolo de una "opinión pública" que se ilusiona a sí misma porque en el fondo así lo quiere ("autosugestión", figura 1); y, en fin, ironía sobre el discurso de los informadores que son, en principio, por profesión, los colegas del periódico, de quienes precisamente se cuestiona la credibilidad tanto por la desenvoltura que uno manifiesta con respecto al contenido de lo que reportan (figura 7), como, al contrario, por el respeto, excesivo para no ser simulado, que otro caricaturista manifiesta con las formas convencionales del lenguaje periodístico (figura 6) —dos maneras discretas de sugerir por qué comienza la "desinformación".

\section{III.3. El lector modelo}

En ese panorama, el caso del dibujo de prensa, que nos interesa más particularmente, presenta como rasgo singular que por construcción, como se ha observado un poco más arribạ, ironizando 
sobre su objeto explícito - tal personalidad a la vista, tal circunstancia "de actualidad"-- ironiza casi inevitablèmente también sobre el periódico mismo donde aparece. ¿Se creerá que sea fácil, por ejemplo, para un Plantu, mirar por nosotros o, incluso, con nosotros lo que sucede en el mundo --y de burlarse- - sin burlarse por ahí de lo que Le Monde precisamente, en la columna vecina o quizá en la página siguiente, nos dice?

Como cada uno sabe, cuando un lector de periódico encuentra a otros lectores de periódico (y es eso precisamente lo que somos), hablan del periódico y se ríen de él. Ahora bien, antes de ser un caricaturista o un autor de tiras "de humor", cada uno de nuestros ironistas es un lector y, en primer lugar, un lector del periódico que lo edita. Ahí encuentra lo que, por definición, constituirá el contexto discursivo inmediato de sus invenciones gráficas o textuales y que, a ese título, le suministra a la vez un discurso de referencia y un blanco privilegiado. Bajo esas condiciones, la irrision, admitida para ejercerse a expensas de otro, se vuelve sobre sí misma (sobre "la institución"). Ése es el riesgo y, de hecho, es el riesgo comunmente aceptado: se rie (un poco) del Figaro en Le Figaro, del Monde en Le Monde, del Canard en Le Canard enchaîné, y así sucesivamente.

Si no se lo acepta, más vale, seguramente, pasarse sin ningún bromista ni burlon. Y si a pesar de todo son necesarias hoy, al parecer, las "imágenes" en un periódico, bastará entonces con acantonarlas en una función puramente documental (ilustrar los textos) o cosmética ("aerear" el formato de la página), excluyendo así de oficio, al mismo tiempo que la caricatura, toda tentación de jugar, irónica o, peor aún, humorísticamente, con la imagen del periódico. Por excesiva que pueda parecer, una prudencia tan forzada tiene marginalmente sus partidarios: los encontramos en Libération, un periódico donde, efectivamente, jamás se ríe uno de Libération. De otros asuntos tampoco, desde el momento en que ese periódico renunció a su gran especialidad en sus orígenes, el retruécano. ${ }^{3}$

${ }^{3}$ Cf. sobre este punto, P. Fiala y B. Habert, "La langue de bois en éclat dans 
Si, de un lado, sería difícil decir lo que ese periódico gana con eso, del otro, se discieme claramente lo que pierde - y que la competencia, en cambio, no olvida explotar. De lo que se priva, y nos priva con tales precauciones, es del metadiscurso de un "lector modelo": dicho de otra forma, de un discurso sobre el discurso del periódico que, sin decirlo, nos indicarla de cierta forma cómo leer el espectáculo del mundo que el periódico nos ofrece un poco como lo hace la mímica del payaso, quien, por su presencia en otro sistema semiótico complejo donde lo cómico tiene también su papel, sabe hacemos comprender, sin decirlo, cómo, en qué modo - ¿la diversión?, ¿la admiración?, ¿la ansiedad?, ¿la confianza?, ¿la sospecha? - conviene que miremos, que "vivamos" uno a uno los diferentes números del circo.

Desde ese punto de vista, el papel del caricaturista en la prensa, como aquel de su homólogo en el circo, rebasa el de un simple animador. En realidad, él ayuda al periodico a desmultiplicar, luego a enriquecer y, finalmente, a mejor dominar el juego de las posiciones y de las relaciones complejas que entran en la definición de su régimen de comunicación con sus lectores. De hecho, la comunicación periodística no se limita a poner en relación un "emisor" con unos "receptores" que intercambiarían entre sí meramente un poco de "información" contra módicas sumas de dinero. Por supuesto, ese intercambio mínimo tiene lugar, pero para que tenga lugar y, sobre todo, para que se renueve (hasta convertirse en una "costumbre" cotidiana), es necesario que el contrato conlleve al mismo tiempo otros contenidos, otros valores más directamente relacionados a la identidad de los dos contratantes: es necesario convertirlos al menos en "socios", sino es que no en "cómplices" —en todo caso en sujetos unidos- en una cierta manera de percibir el mundo y de percibirse mutuamente. ${ }^{4}$

les titres de la presse quotidienne francaise", Mots / Les langages du politique, $21,1989$.

${ }^{4}$ Cf. E. Landowski, "Una semiótica de lo cotidiano (Le Monde, Libération)", La sociedad figurada, op. cit., capítulo vı. 
De ahí, ta necesidad, del lado del "emisor", de "colacar" bien y de ajustar la "imagen de marca" que el períodico ofrece de sí mismo como sujeto enunciador con carácter colectivo. Pero de ahí, también, la utilidad de todo lo que pueda contribuir a prefigurar, esta vez con respecto al enunciatario, una posición de lectura 0 , mejor, un juego de posiciones posibles. En esa optica, el interés "estratégico" del payaso-caricaturista es cláro. Permite al periódico figurar para nosotros, sus lectores, una posición de lectura determinada en relación a los contenidos de la "información". A nuestro entender, esa posición es determinante para la definición del tipo de régimen de enunciación periodístico "posmoderno" actualmente en voga: no es aquella de un lector que ejercería, propiamente dicho, una actividad interpretativa, o de "comentario" autorizado como sucede en el editorial, o incluso en el correo de los lectores, sino aquella de un lector pretendidamente cualquiera, "ingenuo", que (como se dice no ya en la primera página del Figaro sino en la última del Monde) manifiesta lisa y llanamente sus reacciones "vivas", sur le vif, dando por principio libre curso, ante las noticias del día, al juego de las atracciones y de las repulsiones "primarias", a los impulsos del creer y a los movimientos de las pasiones, invitándonos a compartirlas.

Desde esa perspectiva, el humor o, en su lugar, la ironía interviene como un ingrediente necesario, aunque su presencia no sea siempre inmediatamente evidente. Veamos, a manera de ejemplo, la figura 8: semejante "grito del corazon" - hablamos del dibujo, en su contexto- ipertenece verdaderamente al género cómico? Si así es, ¿en qué sentido? Y ¿al servicio de qué, de cuál causa contribuye la ironía en un caso como ése? 


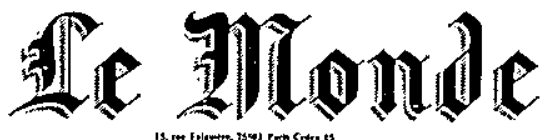

.Jeudi, à 0 heure (heure de Paris), le président Bush a ordonne le bombardement des sites stratégiques Foudroyante offensive alliée sur l'Irak

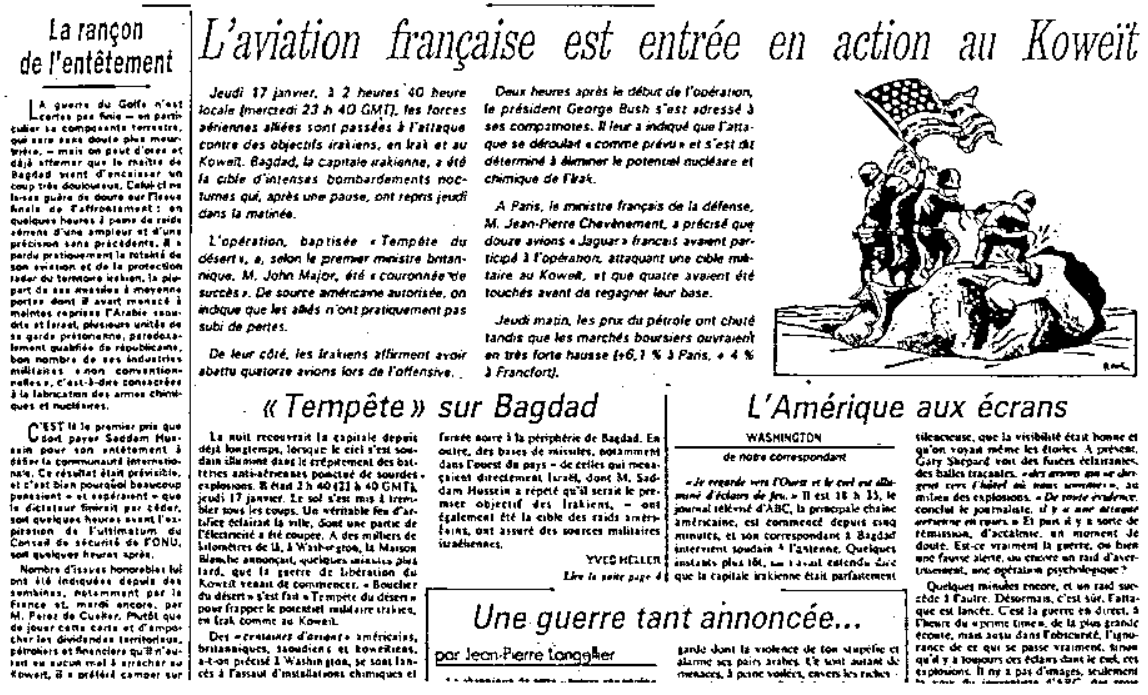

Figura 8: Dibujo de Plantu, Le Monde, 18 enero 1991. 


\section{IV.1. Un investimiento paradójico}

Como el dibujo del 20 de enero examinado más arriba (figura 7), el de la antevíspera (figura 8) condensa, gracias al poder sintético de la imagen, to esencial de lo que podemos aprender al recorrer los títulos que lo rodean en el espacio de la página. En un sentido, se trata de dos "ilustraciones", cada una resumiendo un episodio determinado de un relato de múltiples actualizaciones dado, por otra parte, en expansion en toda la prensa, sin hablar de la televisión. Sin embargo, mientras que el dibujo precedente se alejaba abiertamente del discurso a "ilustrar", dando de éste una versión discretamente antifrástica, aquí, se trata de otro tipo de relación entre la información de base y el đibujo que se superpone: esta vez, no se puede decir que la imagen deconstruye los elementos provistos por el contexto; más bien los reconstruye, pero en el modo hiperbólico. El primer dibujo, al sugerir lo contrario de lo que nos decía su discurso de referencia, desinvestía el sentido de ese discurso; el segundo, no sólo parece asumir el suyo sino lo prolonga, lo refuerza, lo sobreinviste, como se va a ver, por un aporte de nuevos valores.

Constatación trivial, se dirá, ya que una caricatura que no "exagerara" no sería una caricatura. Ciertamente, pero esa caricatura ofrece acá aún algo más específico, y es eso lo que tenemos que aclarar, partiendo de 10 "concreto". ¿Cuál es entonces, de manera precisa, el elemento - el motivo, en el sentido pictórico del término- del cual se puede decir que constituye aquí el objeto de un tratamiento "caricatural"? Se observará que no se trata de ninguna manera de la fisonomía del jefe del Estado iraquí. Tenemos en realidad, en este ejemplo, un retrato más bien "realista", apuntando en todo caso a una "semejanza" que, a propósito del mismo personaje, contrasta con la iconografía fantástica entonces en voga de un extremo al otro de la prensa bien pensante (cf. Anexos 6 a 8). 
En cambio, queda claro que la desproporción entre el tamaño de la cara retratada y la talla, liliputiense, de los cuatro soldados que están montados asaltándola, figurativiza la relación entre las fuerzas en presencia -que, por otro lado, se nos comenta en el resto de la página - sobre un modo que no tiene nada de "realista". Al contrario, el dibujo se emplea de manera sistemática para retematizar el conjunto de las informaciones adyacentes según una especie de pasaje al extremo. La ofensiva en curso sobre Irak se convierte en una ofensiva encarnizada contra un hombre ya caído; el "golpe muy doloroso" que el "maestro de Bagdad acaba de recibir" $\rightarrow$ nos informa ei editorial - se transforma por anticipación en mutilación de su cadáver (una manera como cualquier otra de "vender la piel del oso"); y la "tempestad", de resultados aun no menos inciertos, que acaba de ser lanzada sobre su capital, da lugar al aplastamiento, ya consumado, del monstruo.

Esa última palabra no está de más, ya que si semejante delirio de odio, tan complacientemente expuesto ante nuestos ojos - ipara nuestro próvecho, sin duda, o para nuestro placer, quizá? - reescribe el relato de la actualidad inmediata de la cual el caricaturista se nutre, y lo hace al mismo tiempo mediante la convocación de otro discurso de referencia, más lejano, pero cuyos componentes tanto figurativos como temáticos están bien presentes en nuestra memoria de lectores de imágenes. Se trata, evidentemente, de la iconografía cristiana encargada de celebrar la lucha con el infiel, en particular con su escena central en donde se ve al caballero defensor de la fe enfrentar en combate singular a la encarnacion, por definición bestial y monstruosa, de las fuerzas del mal. Ése es el antiguo motivo que resurge aquí, y no se precisa de más para que, sin encontrar la menor resistencia y para nuestra salud, la bandera estrellada de George Bush -ese amateur de golf que de repente se ha metamorfoseado en arcángel de nuestro tiempo- se transforme en una lanza invencible entre las manos de sus cuatro paladines descendidos del cielo y atraviese el ojo del infiel según el propio gesto de san Jorge, quién, conforme a los decretos de la divina providencia, debía atravesar 
la cabeza infame del dragon. A la prosa del cotidiano se substituye así el discurso hiperbólico y tranquilizador del mito. Resulta que la guerra —ya "limpia", es verdad- se afirma como santa crúzada; el miedo que hubiera podido engendrar da lugar al júbito de un triunfo asegurado; y los escrúpulos morales, si los hubiera, ceden a la certidumbre inquebrantable de los defensores del derecho y de la fe.

Si, como lo hemos sugerido más arriba, el objetivo de la ironía es en definitiva el de estabilizar el sentido (por oposicion al humor, que lo perturba), se trata aquí de una especie de obra maestra del género, aunque paradojica. De un lado, frente a un discurso de referencia que pone en escena todos los elementos de la posible catástrofe, quizá inminente, y de la zambullida en el puro sin sentido, el dibujo de Plantu instala el simulacro de un mundo sensato; prometiendo un pronto regreso al "orden", autoriza ya las carcajadas que celebrarán pronto la victoria, una victoria ineluctable puesto que se merece. Pero por otró lado, ese orden que anuncia al sustituir las certidumbres del discurso de la leyenda a las incertidumbres del discurso de la política, es todavía tan titubeante que la risa del triunfo que puede provocar asumir un simulacro como ése no podría ser jamás, hablando con propiedad, más que una risa histerica. Así, en lugar de dirigirse a la razón al deconstruir un discurso mitificante que nos escondería la "verdad", el ironista —y ahí está lo paradojico— hace aquí exactamente lo contrario: que se trate de tranquilizamos o de hacernos gozar, evoca deliberadamente un motivo mitológico, entre otros disponibles, para recubrir la dura realidad del momento con un velo místico que, visto de más cerca, no se mantiene más que en virtud de la fe (en nosotros mismos) y del desbordamiento de pasiones (contra el Otro), que se supone debemos investir. 


\section{IV.2. Humor y humores}

Desde luego, los estados de alma son cambiantes, por naturaleza. Frente a la misma historia que se prolonga, a la exaltación de un día, podrá muy bien seguir, al otro día, la indignación, marcada por el regreso a posturas enunciativas menos paradojicas.

A partir de ahí, la ironía volverá a su vocación primera, es decir, desmistificadora e, incluso, si hay necesidad, denunciadora, dado que el ironista tiene más de un registro en su arsenal. Cuando el desarrollo de la historia amenazaba con volverse trágico, 1o hemos visto recurrir al registro de una afabulación mítica destinada a reconfortamos psicologicamente: era necesario recuperar la confianza (figura 8). En cambio, ahora que la tensión dramática parece decrecer, ya que se nos dice (siempre de Washington, figura 9) que el campo del más fuerte, el nuestro - el del derecho- - está realmente a punto de vencer, sucede que vuelve a ser posible la práctica de un estilo irónico más clásico y más suelto, proveniente de otro registro, el de la denuncia ética. Con ese nuevo cambio, no pretende más contribuir a la restauración de nuestro "ánimo" sino, más bien, al endurecimiento de nuestra "buena conciencia", proclamando para nosotros que, a pesar de todo, no tenemos ilusiones en relación con los procedimientos de esa guerra pretendidamente "quịúrjica".

Pero "el espectáculo continúa", y es muy posible que volveremos a caer un día, de acuerdo al esquema ciclotímico bien conocido, en la ansiedad de antes del paroxismo de la "crisis" (figura 10) y quizá también - ¿en un mes, en un año? - de la ansiedad en el aburrimiento, síntoma de los periodos de latencia que no engaña jamás (figura 11).

No hay duda que, según las circunstancias, nuestros humoristas sabrán siempre encontrar la manera de regular las modulaciones posibles de nuestros afectos, a menos que ellos mismos no los hayan suscitado primero. Desde ese punto de vista, la semiotica del humor, tal como se práctica hoy en esa parte de la prensa que hemos sobrevolado, nos parece en definitiva inseparable de 


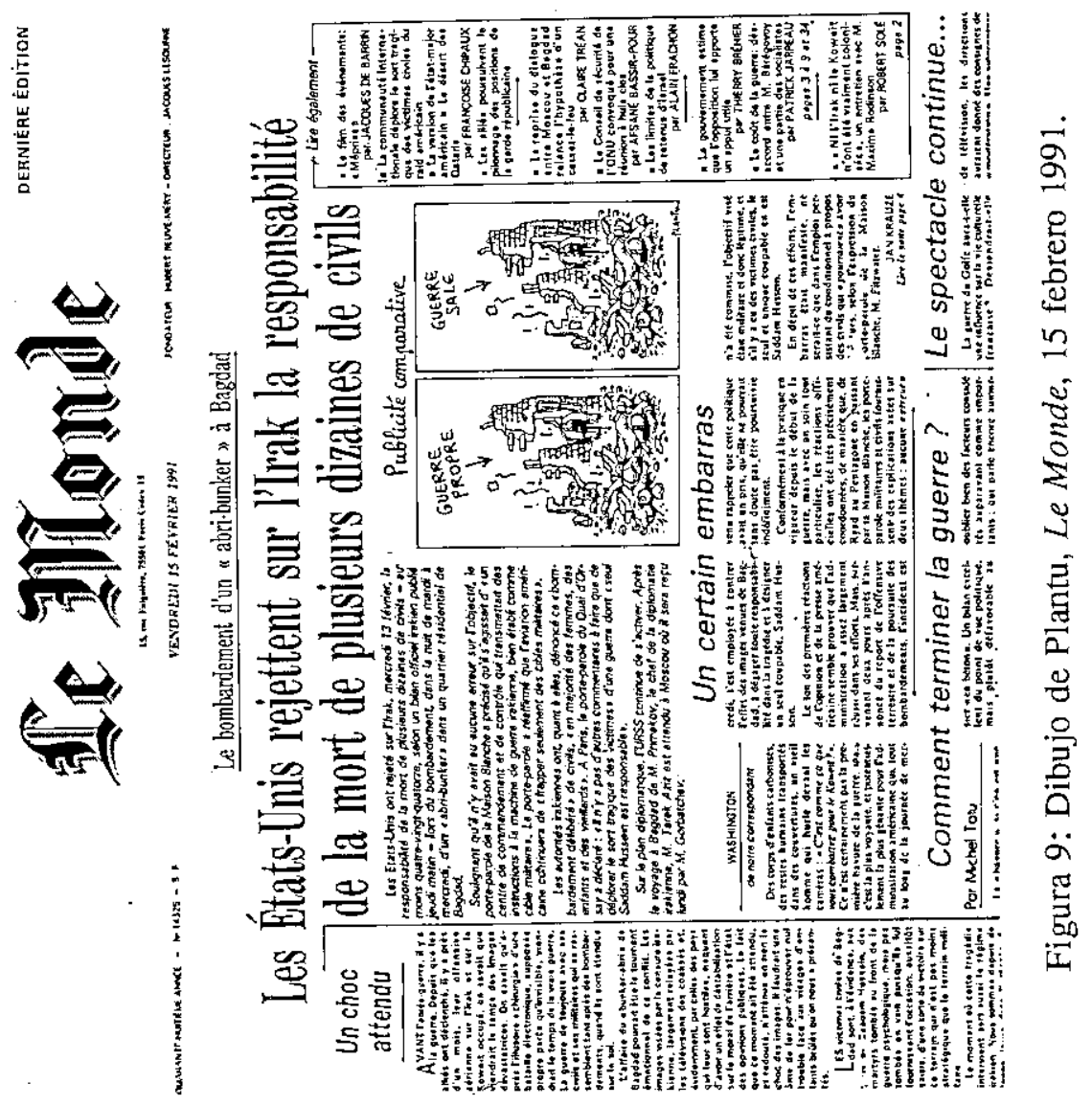


una semiótica de los humores: ¿cómo se engendrán como efectos de sentido?, ¿cómo se transforman?, ¿cómo se enuncian? Si la investigación acerca de ese tipo de preguntas ya se empezo sobre un plano general, ${ }^{5}$ hay en ese marco un capítulo suplementario a considerar que se referiría precisamente a la dinámica de los estados de alma, de las pasiones, de los "humores", durables o cambiantes, que colorean la manera como vivimos nuestras relaciones con lo político por intermedio de las puestas en escena, humorísticas o no, que los órganos "de informacion" nos proponen.

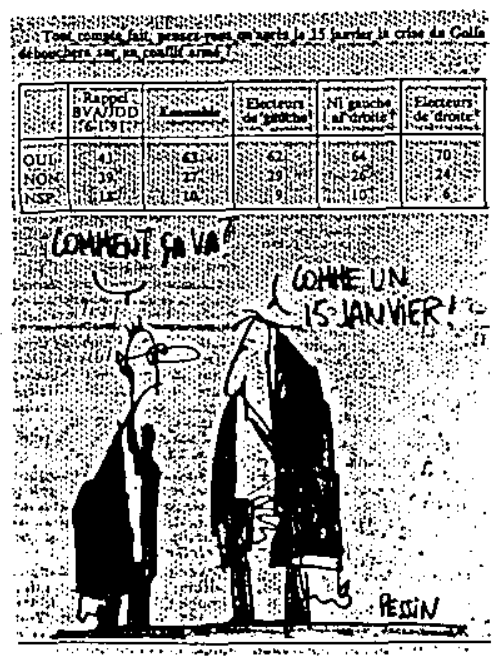

Figura 10: Dibujo de Pessin, Le Monde, 15 enero 1991.
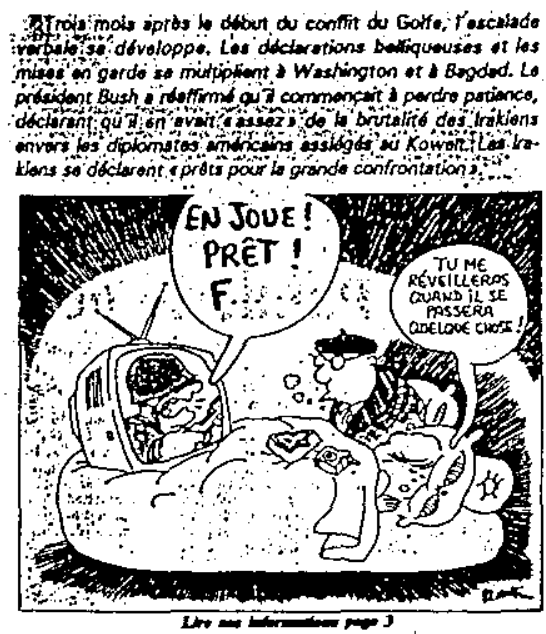

Figura 11: Dibujo de Plantu, Le Monde, 2 noviembre 1990.

${ }^{5}$ Cf. A. J. Greimas y J. Fontanille, Sémiotique des pasions. Des états de choses aux élats d'âmes, París, Seuil, 1991, 336 p. 
Independientemente del tipo de imágenes que hemos examinado y que, para resumir, nos parecen sobre todo combinadas para canalizar "afectos políticos", hay evidentemente varios más, en las pantallas, en los muros e, incluso, en la prensa, que, aunque no recuпеn al registro del "humor", actúan nada menos en el mismo plano —el de los "humores"- y probablemente, en muchos casos, con un impacto más directo y más fuerte. No hay pues lugar para sobrevaluar el alcance de nuestros pequeños dibujos satíricos. Sin embargo, en la perspectiva restringida en la que nos hemos situado, la del periódico, su papel no nos parece ni marginal ni totalmente irrisorio.

Por otro lado, dentro de ese marco limitado, está claro también que todos los buenos sentimientos que, con cara de chiste, la imagen maneja, el texto mismo del periodico nos invita, también, la mayoría de las veces, a compartirlos. No obstante, no se puede decir que haya simplemente redundancia entre los dos discursos. Por el contrario, una vez que habíamos decidido analizar las caricaturas sin separarlas de su contexto, nos ha sido fácil ver que en realidad la imagen y el texto no dicen exactamente la misma cosa. La imagen, en la mayoría de los casos, presupone al texto y, al hablar de $e ̂$, nos hace "vivir" de manera diferente lo que enuncia, sea interviniendo en el plano del creer, por la introducción sistemática de rupturas entre los puntos de vista, sea en el de las pasiones, agregando por lo menos un suplemento de intensidad en su expresión.

Para tratar de justificar esa última disparidad —esa sobrecarga de afectividad confiada a lo "visual"- podría uno pensar en consideraciones en torno a la "decencia": lo que puede ser sugerido por la imagen, no sería de "buen ver" escribirlo negro sobre blanco. Pero habría entonces que admitir, en teoría, que uno de esos dos modos de enunciación, lo visual so pretexto de que sería por naturaleza menos "explícito", más "alusivo", que el otro, el textual podría sin inconveniente servir de canal para la expresión de ciertas "audacias", demasiado crudas para no llegar a ser chocantes si fueran expresadas por escrito. Tal hipotesis, sin embargo, nọ resiste al 
hecho de que en realidad, y de una manera general, la imagen, aunque por caminos en parte diferentes, habla tan claramente como lo hace el texto. A manera de prueba, el viemes 18 de enero de 1991 no había necesidad alguna de una glosa para "explicitar" lo que, en su perfecta indecencia, el dibujo sin palabras que hemos examinado quería decir. No "diciendo" nada, un dibujo dice incluso, muy a menudo, más, y más crudamente si lo quiere, que el contexto lingüístico donde se ubica y que toma a su cargo para deconstruirlo o para reconstruirlo.

Además, en el instante en el que abrimos el periódico, es la imagen, como Gestalt, la que vemos antes que todo lo demás. De esa forma, es ella quien, de golpe, fija para nosotros el humor del día - el nuestro, puesto que a fin de cuentas es de nosotros mismos que por anticipación nos habla ofreciéndonos los simulacros de nuestros propios afectos. Comprendemos entonces por que hay tan poco humor - pèro tanto de ironía - entre las caricaturas políticas de la prensa cotidiana. Su objeto no es aparentemente el de introducir, en el modo de la fantasía individual o del placer gratuito, çualquier forma de desorden semántico que correría el riesgo de oscurecer nuestra percepción del universo político. Representan, por el contrario, en el marco del periódico, espacios de significación privilegiados en la medida que permiten a la institución tomar a su cargo, simulándolo, lo que podría ser nuestro propio discurso si, en política, la palabra pudiera ser dada a simples testigos. Producidos en el interior de un marco editorial a priori más propicio a la afirmación del sentido que a su cuestionamiento, y recibidos como elementos indisociables de un contexto discursivo inmediatamente disponible como garantía de la "verdad" de lo que enuncian, simulan en realidad la irrisión antes que ponerla verdaderamente en acto.

De esa forma, nos dan día con día la "clave", en el sentido musical del término; de nuestra lectura de la actualidad. Como si, en la antesala (y no al margen) del periódico que nos da cuenta del mundo, alguien debiera "hacerla de payaso" y nos contara el periodico para que no nos equivoquemos cuando haya que reír y cuando haya que llorar. 

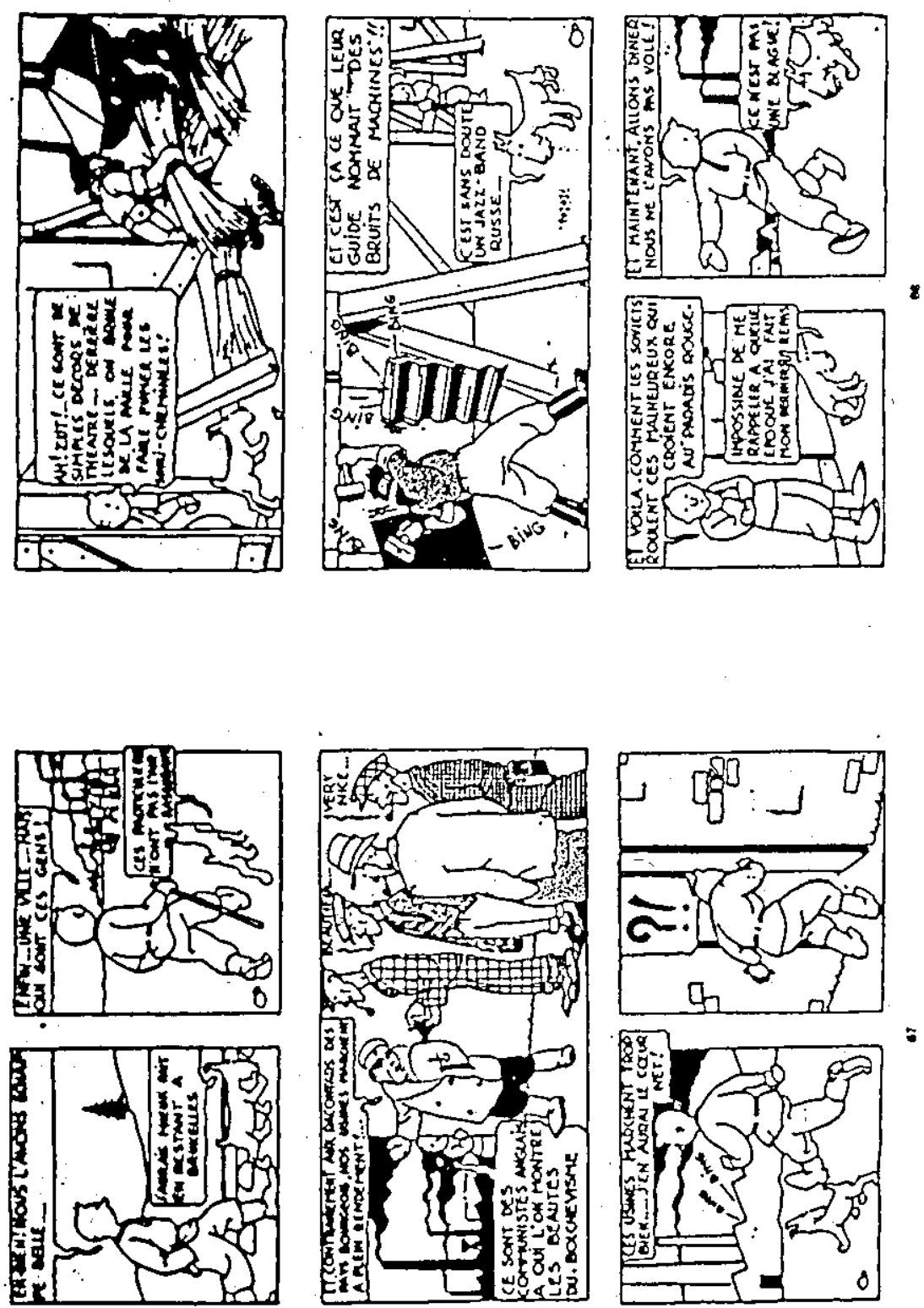

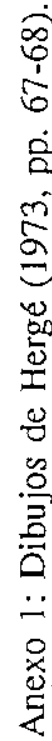
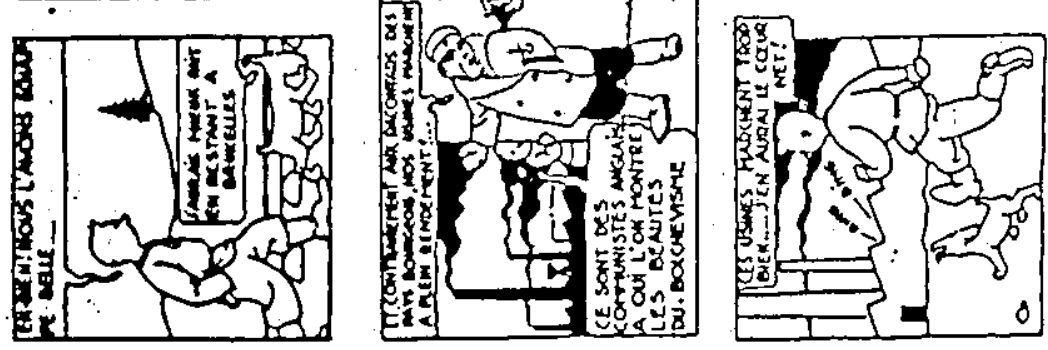

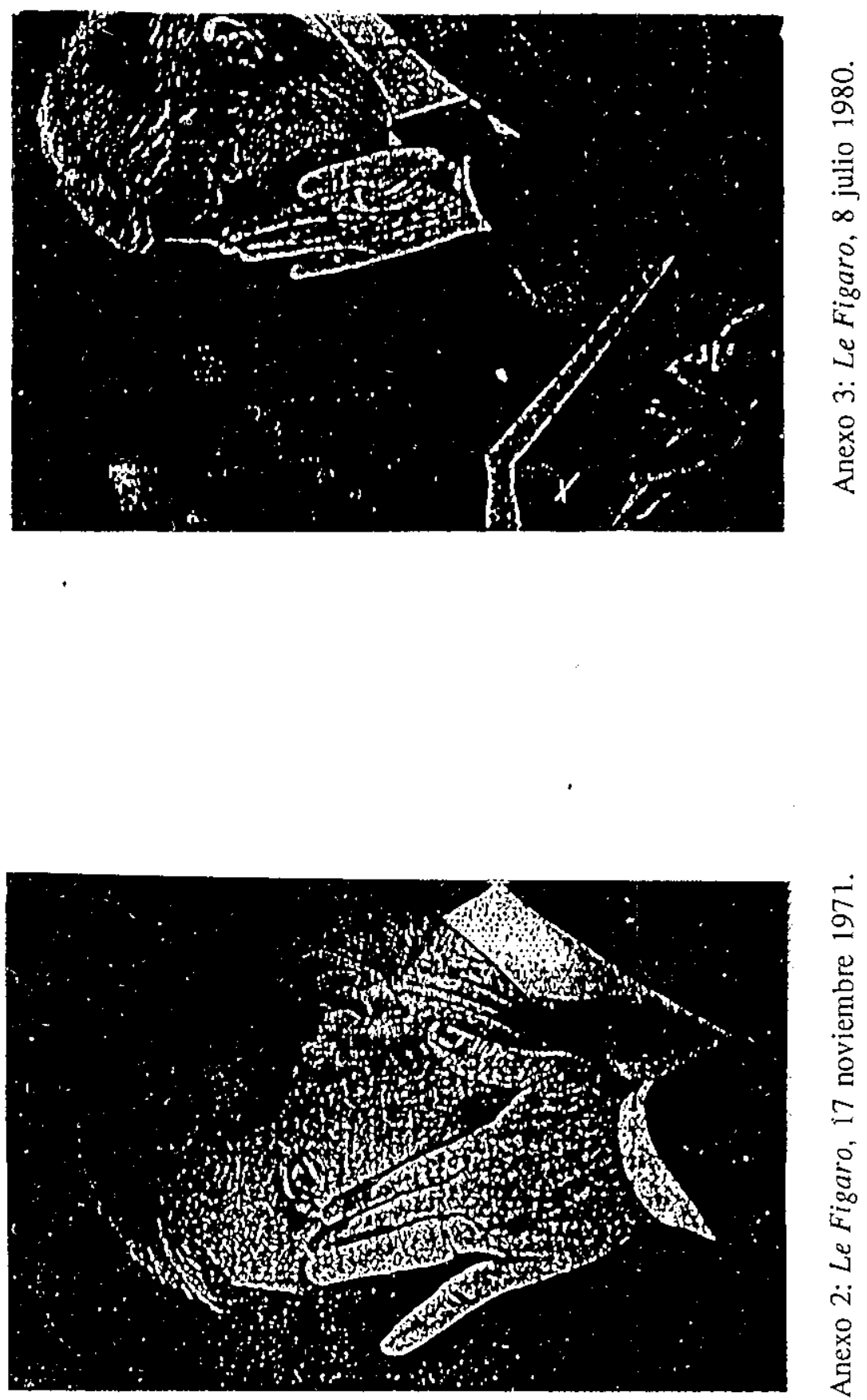


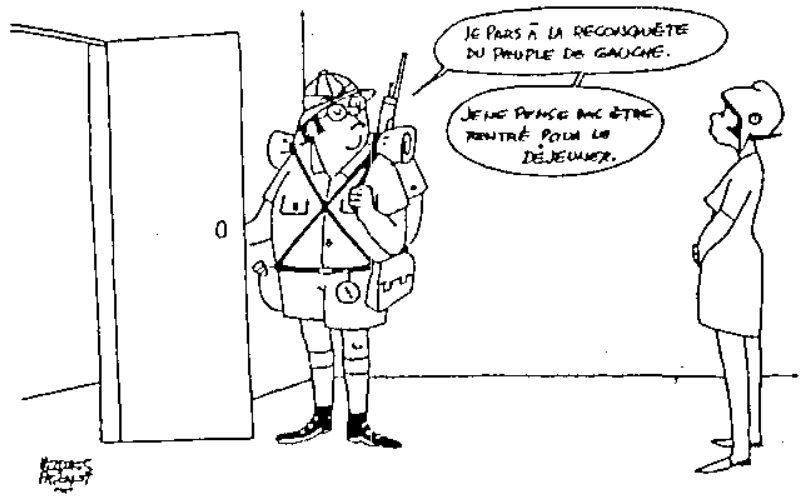

Anexo 4: Dibujo de J. Faizant, Le Figaro, 7 diciembre 1983.

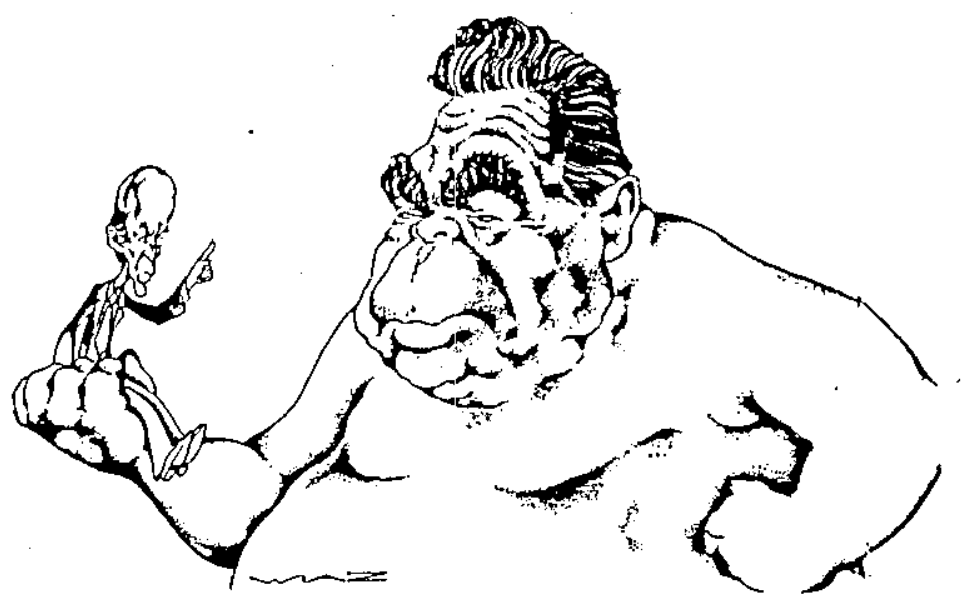

Anexo 5: Dibujo de Wiaz, "Mayo 80- La poignée de main de Varsovie". 


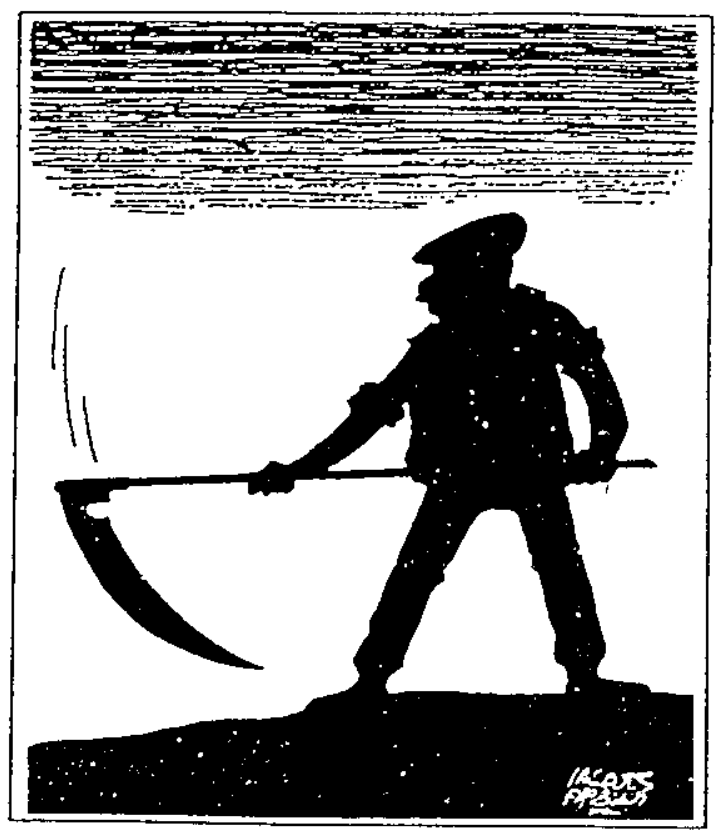

Anexo 6: Dibujo de J. Faizant, Le Figaro, 17 enero 1991.

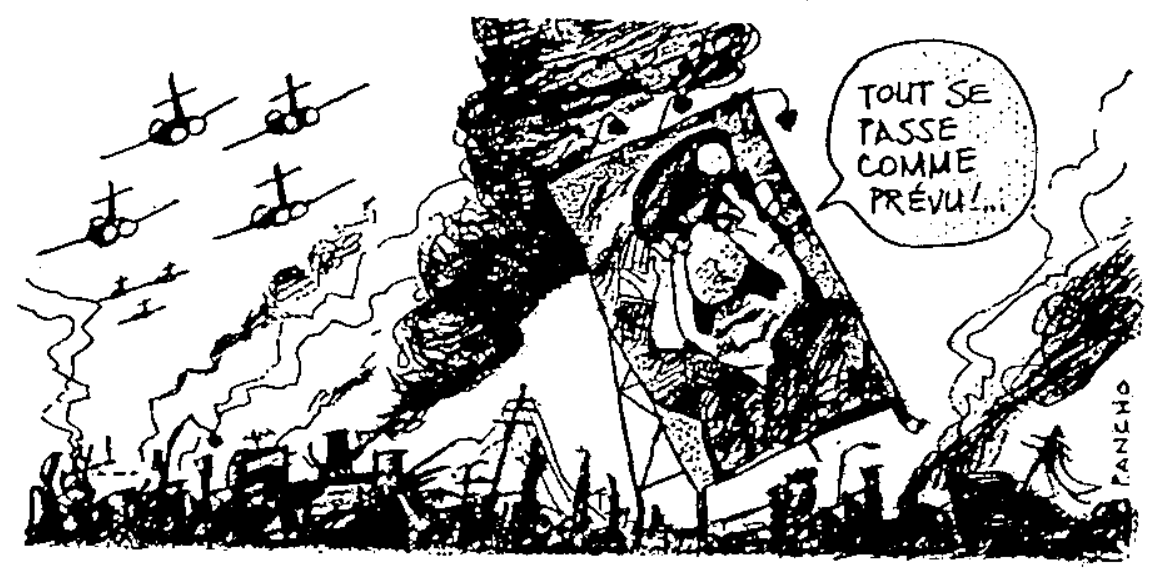

Anexo 7: Dibujo de Pancho, Le Figaro, 18 enero 1991. 


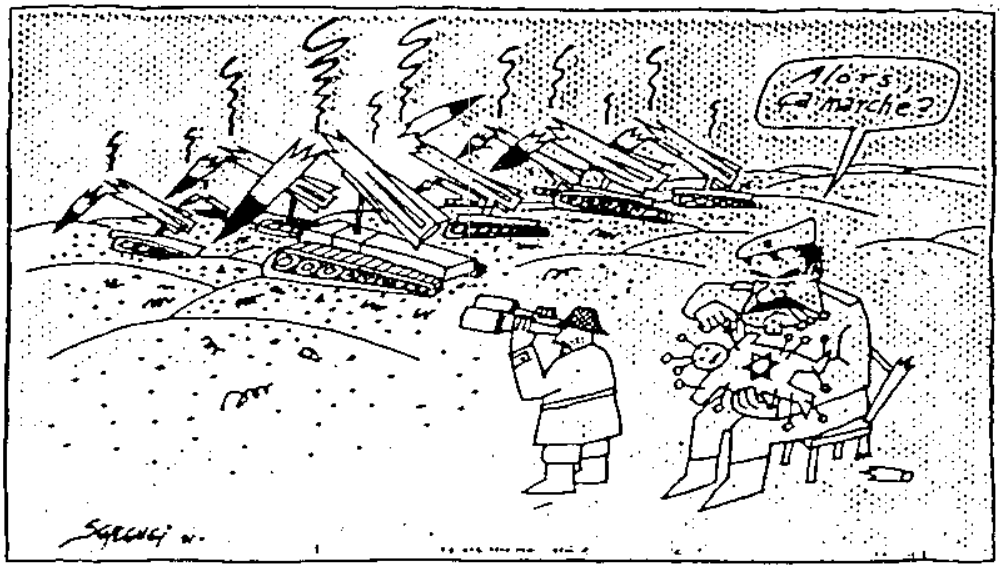

Anexo 8: Dibujo de Serguei, Le Monde, 19 enero 1991.

\section{OBRAS CITADAS}

Falzant (1984), Le beau joli nouveau est arrivé, París, Denoël, $1984,138 \mathrm{p}$.

Hergé (1973), Tintin au Pays des Soviets, in Archives Hergé, París, Casterman, 1973, pp. 39-180 (1a. ed., Bruselas, "Le Petit $\left.\mathrm{XX} \mathrm{x}^{e \prime}, 1929\right)$.

Konk (1977), Demandez les programmes, París, ediciones Minoustchine, $1977,96 \mathrm{p}$.

Plantu (1987), A la soupe, París, La Découverte-"Le Monde", $1987,143 \mathrm{p}$.

TREZ (1987), Trez en campagne, 1986-1987, París, Vilo, 1987, $116 \mathrm{p}$.

Wiaz (1981), Français, si vous saviez..., París, Presses Universitaires de France, 1981, 100 p. 